\title{
MODEM EQUIPMENT FOR THE NEW GENERATION COMPACT TROPOSCATTER STATIONS
}

\author{
Serhii O. Kravchuk, Mikolay M. Kaydenko \\ National Technical University of Ukraine "KPI", Kyiv, Ukraine
}

Background. Modem equipment of tropospheric communication lines is an important component of modern means of telecommunication. The theoretical and practical aspects of choosing a preferred embodiment of modem equipment, taking into account the aggregate indicators of quality.

Objective. Presentation features the construction of modem equipment of the tropospheric stations of new generation that can provide high data transfer rates with guaranteed quality of service in complex stationary and non-stationary noise inherent in tropospheric channels.

Methods. This goal is achieved by using new technical and architectural solutions to build a modem equipment, spectrally efficient modulation types and coding algorithms of effective adaptation to changing operating conditions. Feasibility of the proposed approaches to the construction of the modem hardware is fulfilled on a prototype of the equipment based on the HSMC ARRadio Daughter Card debugging modules.

Results. The features of constructing of modem equipment of troposcatter stations with high data transfer rate are provided. To reach the limiting parameters of such stations proposed in the application of modem equipment of new technical and architectural solutions, spectrally efficient modulation types (OFDM plus linear modulation) and error-correcting coding, efficient algorithms of adaptation to changing conditions of work, the SDR technology, frame structures of physical layer. The variants of the configuration of modem equipment in relation to the modes of operation of compact troposcatter station.

Conclusions. Ways of improving modem performance to improve the efficiency of modern compact troposcatter radiorelay stations.

Keywords: tropospheric communication; modem equipment; adaptation; software-defined radio; channel configurations.

\section{Introduction}

The troposphere is a lower layer of Earth's atmosphere. Its upper limit is at a height of about $10 \ldots 12$ $\mathrm{km}$. In the troposphere is always a local volume heterogeneity caused by different physical processes taking place in it. Radio waves UHF band and centimeter wavelengths (especially in the band 0.3...5.0 $\mathrm{GHz}$ ) can dissipate these inhomogeneities. Given the fact that heterogeneity are at high altitude, it is easy to imagine that they are scattered radio waves can extend for hundreds of kilometers. The effect of such a distant tropospheric propagation was opened in the early 50s of last century. Its practical application has made it possible to build a new type of microwave links - tropospheric radio relay lines with the distance between adjacent stations from $150 \mathrm{~km}$ to $300 \mathrm{~km}$, and in some cases from $600 \mathrm{~km}$ to $800 \mathrm{~km}$ and more.

Despite the fact that troposcatter radio relay system (TRRS) is much more difficult to implement, and the capacity of lower than that of microwave systems (RRS) line of sight, thanks to length of flight TRRS found quite widely used, especially for military, special services, rescue services and emergency situations [1-3]. Deploying troposcatter stations does not put forward difficult requirements to terrain. No need to install high towers needed in case RRS for line of sight [4-5].

The basis of troposcatter communication radiolines are two mechanisms of propagation, at ranges of over $60 \ldots 70 \mathrm{~km}$ - scattering of radio waves by the inhomogeneities of the troposphere; at short intervals (less than $60 \ldots 70 \mathrm{~km}$ ) - diffraction propagation. So stations are designed to work in the presence of both mechanisms of distribution, called for transhorizon communication systems.

The main features of tropospheric propagation associated with the physical nature of this phenomenon is fading very large area to spread and fading of the signal at the receiver input, which are selective in frequency character [6-10]. This appears multipath effect, due to the fact that the length of the rays passing through different parts of the volume, where the scattering is different. This leads to distortion of signals transmitted form and volume scattering can be regarded as quadripole, which has limited bandwidth.

In these conditions to provide stable connection have to raise energy parameters of equipment TRRS, achieved an increase transmitter power, use larger antennas, use of low noise amplifier at the receiver input, and use of more effective methods of formation and signal processing while taking in order to reduce the ratio signal to noise ratio at the receiver input at which performance standards are provided to the channel quality indicators and very high throughput.

The disadvantages of traditional means of transhorizon communication relay include: poor communication reliability in terms of interference; large size and power consumption and, consequently, a large number of vehicles, no automatic antenna-mast devices; 
low characteristics of electromagnetic compatibility; lack of unified radio relay stations with systems management and lack of effectiveness of functional control and diagnostics. One of cardinal decisions on leveling of the specified shortcomings of traditional TRRS when saving necessary noise immunity in the conditions of multipath fadings is creation of effective portable TRRS of new generation which basic principles of creation were provided in [11-12].

Currently several companies presented their development of compact TRRS. Thus, the company TeleCommunication Systems Achieves Unprecedented Performance in partnership with Comtech Systems presented the development TRRS «TCS 3T». Using a 500-watt solid state power amplifier and SSPAs (solidstate power amplifiers) of Comtech, the system provides data rates up to $50 \mathrm{Mbit} / \mathrm{s}$ over a distance of 100 miles. The company since 2009 produces new seals digital equipment CSM8100, specifically designed for operation in the ground tropospheric lines and CS4400 new frequency converter designed for operation on tropospheric lines and lines of sight. Raytheon Company has developed TRRS BLOS-T (Beyond Line of Sight Troposcatter Communications) C-band [13].

Implementation of the new generation of portable TRRS has been treated with highly effective specific channel-forming equipment, based on a modem device [14].

The purpose of this article is to describe the main features of the construction of modem equipment of the new generation of troposcatter stations. Such stations will be able to provide high data transfer rates with guaranteed quality in complex stationary and nonstationary noise inherent in tropospheric channels.

\section{Configuration of The Station Equipments}

\section{A. Requirements for modern troposcatter communication stations and them modem equipment}

When creating a modern troposcatter communication station must be made number of specific requirements, namely. The communication range determined by the destination station, and can be from tens to hundreds of kilometers. Range of frequencies of work of station on average and small ranges (to $300 \mathrm{~km}$ ) is recommended to choose at frequencies of $4 \ldots 5 \mathrm{GHz}$. The station should be able to work in three different modes of propagation: troposcatter, diffraction and line of sight. Switching between modes should be automatic, depending on the settings. Difficult conditions at a troposcatter communication require the use of multi-level adaptation: time within the operating frequency band (adaptive modulation and coding); frequency, which provides selection of the optimum operating frequency and the optimum operating frequency band; spatial, involving the use of multi-antenna technology and in particular MIMO (Multiple Input - Multiple Output) technology; interlayer, providing optimum utilization of adaptive modulation and coding and Hybrid automatic repeat request (HARQ) technologies. Adaptation of the station to changing conditions of work must be carried out automatically with a minimal delay without interrupting the session. There is a support of the high data transfer rate of all operating modes of stations due to optimally select the desired mode, the high reliability of data transmission at a high availability factor of radio-line, high spectral efficiency of the communication channel and continuous, non-destructive control of the communication channel status on the basic parameters and simultaneous transmission in the communication channel: information channel, channel of voice calls and overhead information channel. Using of the packet transmission to support a plesiochronous digital hierarchy. The automatic adjustment mode of antennas according to the built-in positioning system is supported. A simple, user-friendly interface to control the station is present. Station control system should be built using the Linux-based operating system. The station should have block and modular architecture for providing creation of various options of a configuration of station to an opportunity. The station should have the built-in system of diagnostics of operability of all main units and modules. Time of deployment of station has to be minimum possible.

\section{B. Options configuration of the station equipments}

Modern troposcatter station should be able to work in three modes. Indirect visibility using tropospheric scattering of radiowaves. This mode provides maximum communication range at the maximum transmitter power. Data transmission rate is minimal (from hundreds of kbps to $2 \mathrm{Mbps}$ ), due to the presence of deep frequency selective fading including daily and seasonal nature. Indirect visibility using diffractive scattering by an obstacle. In this mode, the range of up to $70 \mathrm{~km}$ at a maximum transmission power can be ensured. Data transmission rate is average (to $4 \ldots 8 \mathrm{Mbps}$ ) due to the indirect visibility and the inability to use a multi-position modulation. Line of sight, in this mode, at low power of transmitter provides maximum data transmission rate (to 20 Mbps), communication range is determined by the height of lift station antenna.

The choice of working hours of station is carried out from the control panel, with separate modes for each set of transmission profiles can be provided, which is installed by downloading the appropriate software. Time of initialization of the mode makes no more than 3-5 minutes. Depending on working hours of station for ensuring the maximum capacity various options of a 
configuration of the equipment, or various options of a complete set of station can be used.

The structure of the troposcatter communication station is presented in a general view in Fig.1.

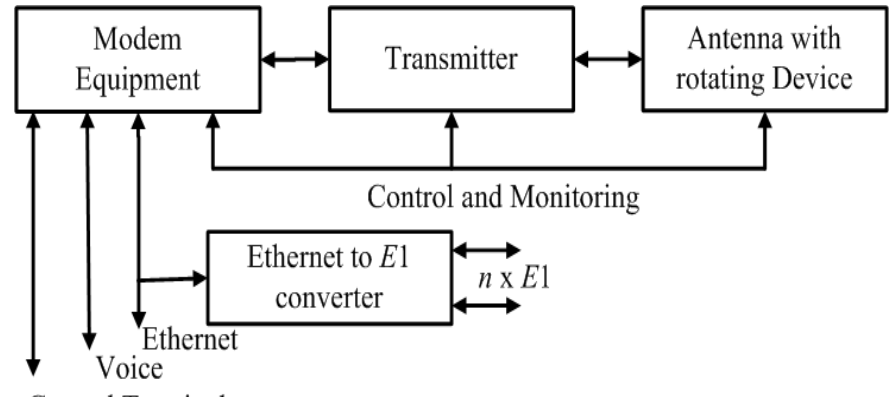

Control Terminal

Fig. 1 General structure of troposcatter communication station

The simplest option of a station configuration is single-channel station with one transceiver and one antenna. This option has the only advantage - cost and can be used only in the mode of line of sight as in other modes can't provide the guaranteed communication quality.

The two-channel station with a polarizing decoupling of channels assumes use of two transceivers, the twochannel modem and one antenna system with a polarizer. In this configuration the potential information transfer rate can be increased twice in comparison with singlechannel. At this configuration providing the guaranteed communication quality in the troposcatter mode is also difficult.

The two-channel station with a spatial decoupling of channels assumes use of two transceivers, the twochannel modem and antenna system with two antennas. Information transfer rate can be twice higher, than at a single-channel configuration, the MIMO technology is used. The station can work in all modes, providing at the same time the guaranteed communication quality.

Dual-channel station with independent channels. Such configuration differs from previous in a possibility of operation of each of channels as independent. Each channel has the carrier frequency and bandpass range. The configuration can be selected programmatically and be used as additional option of setup of station for other dual-channel configurations. In the troposcatter mode such configuration allows to realize adaptation of station both on operating frequency and on bandpass range without interruption of communication. The structure of the equipment of station for dual-channel configurations is shown in Fig.2.

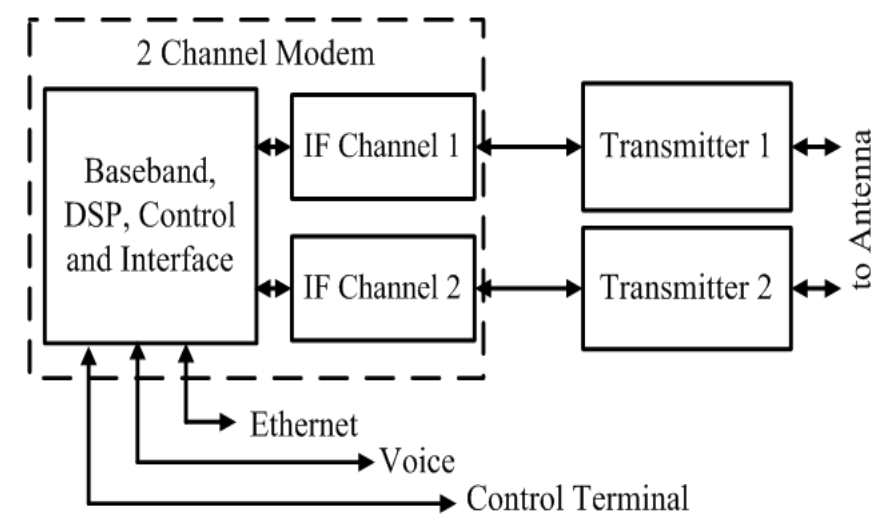

Fig. 2. General structure of the station equipment for dual-channel configurations

Multi-channel station with two spatial (polarizable) channels and to four frequency channels in each spatial. This configuration of station provides use of two transceivers and to four modem modules. Each modem module is used as independent frequency channel with the carrier frequency, bandpass range and system of temporal adaptation. In the troposcatter mode the multichannel station provides the maximum throughput reaching $80 \mathrm{Mbps}$ with the guaranteed communication quality. One of the frequency channels is used as test for the frequency adaptation of station. The structure of the equipment of station for a multi-channel configuration is shown in Fig.3. In comparison with a dual-channel configuration in the modem equipment the unit of combining/separation channel and the Real Time Ethernet Switch for the combining Ethernet flows of each frequency channel is added. The voice channel and control link and monitoring of station is always supported in an information flow of the first modem channel.

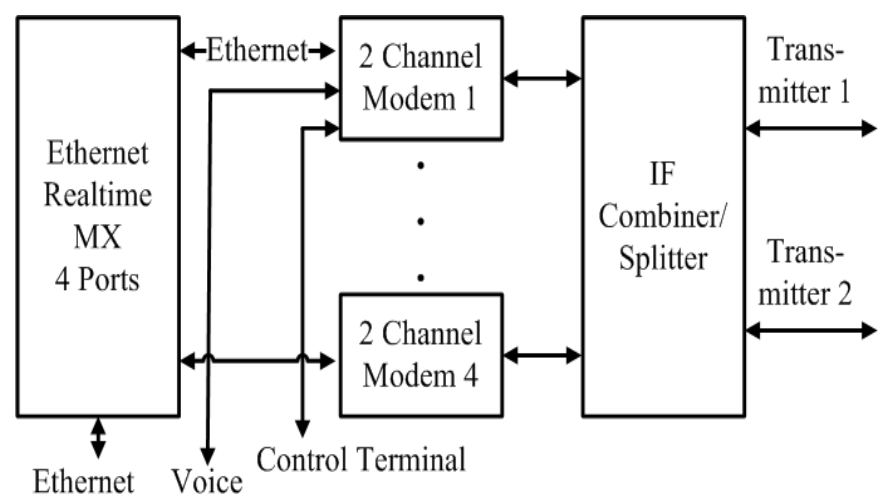

Fig. 3. General structure of the station equipment for a multi-channel configuration

\section{Structure of the modem equipment of the modern troposcatter station}

The modem equipment of troposcatter station is its most important part. It provides modulation, 
demodulation, formation of information, voice and official data streams in an air-interface and the wireinterface, multi-level adaptation of station to the changing working conditions, synchronization, a choice of the working modes of station, control of station and its separate units, condition monitoring of station, etc.

The modem equipment represents the full-function dual-channel modem module which is built on the basis of the SDR (Software-defined radio) technology together with the SoC (System-on-a-Chip) technology. The basic structure of the modem module of station is shown in Fig.4.

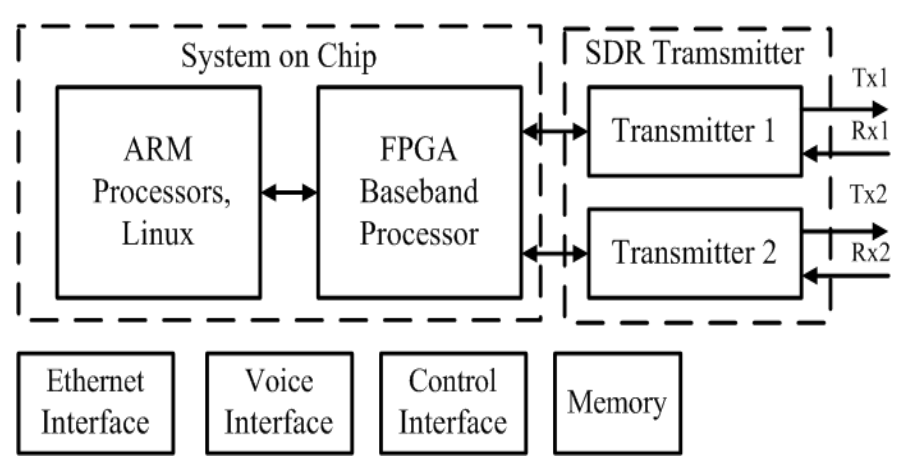

Fig. 4. Basic structure of the modem module of troposcatter station

SDR Transmitter consisting of two identical modules executes functions of the dual-channel receiver, the transmitter and the generator, and also the general control of the module and an exchange with external devices.

By the functions of the receiver, which is based on the direct conversion scheme include: a low-noise amplifier, the automatic gain control circuit, IQ demodulator, an analog low-pass filter, an analog-digital converter (ADC), a digital main filter selection. For transmitter function, which is built on the scheme with direct conversion are output amplifier, the IQ modulator, an analog low-pass filter, digital to analog converter (DAC), digital filter to get rid of the spurious. As a generator used controlled reference oscillator with temperature compensation, generation of intermediate frequency is carried out by digital frequency synthesizer, independent receiver and transmitter. In addition the module has an integrated control system, the control module status and the communication interface with the baseband processor and an external control device.

SoC module consists of a Field-Programmable Gate Array (FPGA) block, and two Acorn RISC Machine (ARM) processors. On FPGA realized two-channel baseband processor, that performs functions: communication with ADC/DAC SDR module, the OFDM modulator/demodulator, mapper/demapper, the encoder/decoder with forward error correction, generating control frequency synchronization, signal phase and timing synchronizer, the interleaver/deinterleaver, frame generator, a scrambler/descrambler, estimates of the average Signalto-Noise Ratio (SNR), modulus of adaptive modulation and coding, exchange with ARM processors via direct memory access (DMA) buffer.

On ARM processors under control of the Linux operating system, Media Access Control (MAC) level of the wireless interface and MAC level of the wire interface and interaction in between, an exchange with Baseband Processors, implementation of algorithms of Adaptive Modulation and Coding (AMC) and frequency adaptation and control of the adaptation modes, support of exchange protocols of external devices, control of the transceiver and antenna system, the general control of station, support of the channel of a voice communication, formation of a group data stream, the controlling user's interface, support of interaction with the external terminal of control is realized.

Modules of the hardware Ethernet interfaces, the control and controlling interfaces, a voice communication, and also random and long-time (flash) access memory also are a part of the modem.

\section{Features Modem Equipment}

\section{Modulation and noiseless coding}

Providing high-speed transmission of information at high spectral efficiency in the high reliability transmission of troposcatter channels require proper selection of type of modulation and error-correcting coding.

For systems which work in conditions the close to the channel to Additive white Gaussian noise (AWGN) (the mode of line of sight of station) it is enough to use multiposition modulation and noiseproof codes with a high speed of coding. In case of the tropospheric channel presence of multipath radio propagation and frequency selective fadings requires use of OFDM modulation together with the linear multiposition modulation, highly effective codes with forward error correction and systems of adaptation on the basis of change of speed of modulation and coding.

OFDM modulation which is used provides use of 256 subcarriers from which information are 192, and a protective interval with a possibility of change of its duration $(1 / 4,1 / 8,1 / 16$ and 1/32) for fight against the intersymbol distortions in the modem equipment. The distance between subcarriers $\Delta f c$ changes depending on the operating frequencies band. Based on the analysis of the accepted and transferred characters on pilot subcarriers the assessment of complex transmission ratio of the channel for operation of a channel equalizer, phase and frequency shifts for timing circuits is carried out.

Each subcarrier is modulated with use of the quadrature modulation. BPSK, QPSK, QAM16, QAM 64 
for the tropospheric and diffraction modes, and also QAM 256 for the mode of direct visibility are used. As noiseproof coding with forward error correction the concatenated codes (the convolutional code and Read Solomon code) with different speeds are used. Optionally there can be uses block turbocodes (Turbo Product Codes).

\section{E. Features of a choice of profiles of transmission for the adaptive modulation and coding}

To work effectively in a non-stationary channel conditions using adaptive modulation and coding (AMC), which is one of the components of the channel adaptation. The AMC system is used as the basic energy estimate channel state: the effective SNR for OFDM symbol interval; dispersion of effective SNR, as measured on the interval data frame.

The estimate Bit Error Rate (BER) can be used as an additional evaluation. The algorithm of the AMC system is built on the basis of the original highly efficient fuzzy inference algorithm [15].

Application of AMC for the single-carrier systems and for systems with OFDM in spite of the similarity of the principles of has some differences arising from the OFDM-signal properties, so the following features select error-correcting code parameters were taken into account, and modulation rate, resulting from the properties of OFDM signals [16]: minimum unit within which the modulation rate and the parameters of error-correcting code must be permanent, is an OFDM symbol, so the adaptation is possible in increments of up to one symbol; OFDM symbol in the frequency domain is consists from subcarriers, the theme of number $N$ is determined by the dimension of the Fourier transform, and respectively multiply two degrees; at its destination subcarriers are divided into data subcarriers $N$ data, pilot subcarriers $N$ pilot and null subcarriers $N z e r o s$, uses $N=256$, wherein $N$ data $=192$; symbol rate within OFDM symbol is always the same (not dependent on the modulation rate) and uniquely is dependent on Ndata; limitation on symbol rate and thus the size of the coded data block leads to a limited number of embodiments used block codes, the most optimal are perforated codes.

Use as a basic assessment of effective SNR imposes the following basic requirements for the selection of the parameters of error-correcting code and modulation rates: when choosing the parameters of error-correcting code and modulation rate, it is necessary to maximize the distance between the neighboring profiles (the difference in SNR), which should be on the opportunity to be the same for all profiles; the minimum distance between the profiles is determined by the precision attainable SNR estimation; the number of transmission profiles selected based on the minimum distance between the profiles; forward error correction (FEC) codes used should effectively correct both single and block errors.

To provide efficiency of the communication channel in the troposcatter mode additionally introduced transmission profile with enhanced noise immunity. A feature of this profile is to use the minimum bandwidth, BPSK modulation and direct spreading using a length 13 Barker code having minimum sidelobes of the autocorrelation function. This profile is used only for the transmission of voice service and data streams.

\section{F. Frequency adaptation}

The frequency adaptation is used in the troposcatter mode. The task of the frequency adaptation is the choice optimum from the point of view of throughput of frequency band in the range of operating frequencies of station at the conditions of existence of the long frequency selective fadings (duration of fadings exceeds duration of several frames) and the interference (structured and unstructured). Two stages of adaptation are used: an initial choice of frequency and adaptation in an operating mode of station. The assessment of link state of communication is carried out by means of the analysis of amplitude-frequency characteristic (AFC) of a through path of transmission (rough estimate) in the selected frequency band of the maximum width $(7 \mathrm{MHz})$. In case of a rough estimate the least subject is selected to the long frequency selective fadings frequency band which can be less maximum. A rough estimate is performed at the initialization stage and optionally select a new frequency band by means of a scanning operation. For an accurate assessment in addition to frequency response analysis is carried out the analysis of the energy characteristics of the channel and noise immunity for the base transmission profile. Select a band with maximum energy reserve and maximum throughput.

Frequency adaptation during operation is carried out in the presence of more than one channel, which can run as an independent. Interactions with other types of adaptation: time adaptation (the adaptive modulation and coding) is carried out only after the frequency adaptation; estimates the link states which are come into in case of AMK are used as necessary for exact frequency adaptation; spatial adaptation can be combined with the frequency adaptation in case of use of each spatial channel as independent.

Existence in station of the mode of the frequency adaptation and opportunity to set slot pitch of frequencies with an accuracy up to $10 \mathrm{kHz}$ allows to work without preliminary frequency planning and "rigid" fixing of a grid of operating frequencies.

G. The use of SDR technology

The use of SDR technology in conjunction with SoC technology provides the following key features to create a modern modem equipment troposcatter station: Use 
multiple profiles to load the configuration station, depending on the selected operating mode; compromise the allocation of resources for the implementation of high-speed and low-speed processes the digital signal processing, algorithms, decision making and control algorithms between the processor cores and FPGA; implementation mode of adaptation in frequency with a quick change of the carrier frequency and bandwidth through the use of digital frequency synthesizer and a set of software-controlled analog and digital filters, the main selection with preset settings profiles coefficients; implementation mode of adaptive modulation and coding to quickly change the profile, implemented on FPGA then control system of decision-making, implemented on a processor ARM; software management features two independent channels simultaneously and implementation of spatial modes of adaptation; implementation of the MAC-level wired and wireless interfaces on a single high-performance chip that allows you to provide the required performance; software implementation of the protocols and modem equipment work stations at high-level language that allows you to speed up the development process; support software interfaces with peripheral equipment, and the required data transfer protocols; management of work stations and modem equipment with a single operating system based on Linux; accelerating the development process through a software implementation of protocols and modem equipment work stations at high-level languages, as well as in-circuit simulation (HIL simulation) implemented solutions.

\section{H. Physical Layer Frame Structure}

In station the mode of the frequency FDD duplex and frame structure of data transfer is used. Frames of direct and reverse channels are identical. Each frame contains a preamble, a frame header (Frame Control Header - FCH) and data packets (DL or UL burst). Physical layer for tropospheric propagation and diffraction modes is based on the use of modulation OFDM. frame duration may vary depending on the operating conditions of the station sets $1,2,5,10 \mathrm{~ms}$. The base is a frame duration of $5 \mathrm{~ms}$. Table 1 shows the parameters of OFDM symbol transmission rate and the number of symbols for this frame length for different signal bands, and a cyclic prefix duration $1 / 8$.
TABLE I. PARAMETERS OF OFDM SYMBOL TRANSMISSION RATE

\begin{tabular}{|c|c|c|c|c|c|}
\hline $\begin{array}{l}\text { Chan- } \\
\text { nel size } \\
\text { (MHz) }\end{array}$ & $\begin{array}{l}\text { OFDM } \\
\text { Symbol } \\
\text { Time } \\
\text { (ms) }\end{array}$ & $\begin{array}{l}\text { Samp- } \\
\text { ling } \\
\text { Freque- } \\
\text { ncy (ms) }\end{array}$ & $\begin{array}{l}\text { Symbol } \\
\text { Rate } \\
\text { (MBd/s) }\end{array}$ & $\begin{array}{l}\text { Bit Rate } \\
\text { 64-QAM } \\
\text { (Mbps) }\end{array}$ & $\begin{array}{l}\text { Number } \\
\text { OFDM } \\
\text { Symbol/ } \\
\text { frame }\end{array}$ \\
\hline 1,25 & 0,2 & 1,44 & 0,96 & 5,76 & 25 \\
1,5 & 0,1674 & 1,72 & 1,1467 & 6,88 & 29 \\
1,75 & 0,1440 & 2,0 & 1.333 & 8,0 & 34 \\
2,5 & 0,1 & 2,88 & 1,92 & 11,52 & 50 \\
3,0 & 0.0837 & 3,44 & 2,2933 & 13,76 & 59 \\
3,5 & 0,072 & 4,0 & 2,6667 & 16,0 & 69 \\
3,75 & 0,0667 & 4,32 & 2,88 & 17,28 & 75 \\
4,5 & 0,0558 & 5,16 & 3,44 & 20,64 & 89 \\
5,0 & 0,05 & 5,76 & 3,84 & 23,04 & 100 \\
5,25 & 0,048 & 6,0 & 4,0 & 24,0 & 104 \\
6,0 & 0,0419 & 6,88 & 4,5867 & 27,52 & 119 \\
7,0 & 0,036 & 8,0 & 5,3333 & 32,0 & 138 \\
\hline
\end{tabular}

Physical layer mode for the line of sight is based on the use of linear modulation. Two variants of the frame duration of 1 and $2 \mathrm{~ms}$. Table 2 shows the transmission rate and the number of frames to frame $1 \mathrm{~ms}$ duration with two versions of the signal bandwidth and roll-off index (roll-off factor) 0.25 .

TABLE II. TRANSMISSION RATE AND THE NUMBER OF FRAMES

\begin{tabular}{|c|c|c|c|c|}
\hline $\begin{array}{c}\text { Channel } \\
\text { size } \\
\text { (MHz) }\end{array}$ & $\begin{array}{c}\text { Symbol } \\
\text { Rate } \\
(\mathbf{M B d} / \mathbf{s})\end{array}$ & $\begin{array}{c}\text { Bit Rate } \\
\text { 16-QAM } \\
\text { (Mbps) }\end{array}$ & $\begin{array}{c}\text { Bit Rate } \\
\text { 256-QAM } \\
\text { (Mbps) }\end{array}$ & $\begin{array}{c}\text { Number } \\
\text { of PSs/ } \\
\text { frame }\end{array}$ \\
\hline 20 & 16 & 64 & 128 & 4000 \\
28 & 22,4 & 89,6 & 179,2 & 5600 \\
\hline
\end{tabular}

I. Research of the modem equipment prototype

To implement these features previously modem equipment is currently undergoing experimental research prototype of such equipment on the basis of HSMC ARRadio Daughter Card debugging modules. On the basis of this module was implemented by a dual-channel SDR Transmitter and SoCKit - the Development Kit, based on which the system-on-chip peripherals, and also has been implemented. The manager operating system used by Linux. During the tests are also used engineering calculation package Matlab R2015b for hardware and software simulation (Hardware-in-the-Loop Simulation, HIL) to develop solutions.

Appearance of a prototype is shown in Fig.5. In Fig.6 shows a signal spectrum at baseband, and Fig.7 shows the signal constellation at the demodulator input. The research prototype demonstrates the feasibility of the proposed approaches to the construction of highperformance modem equipment for a new generation of troposcatter radiorelay stations. 


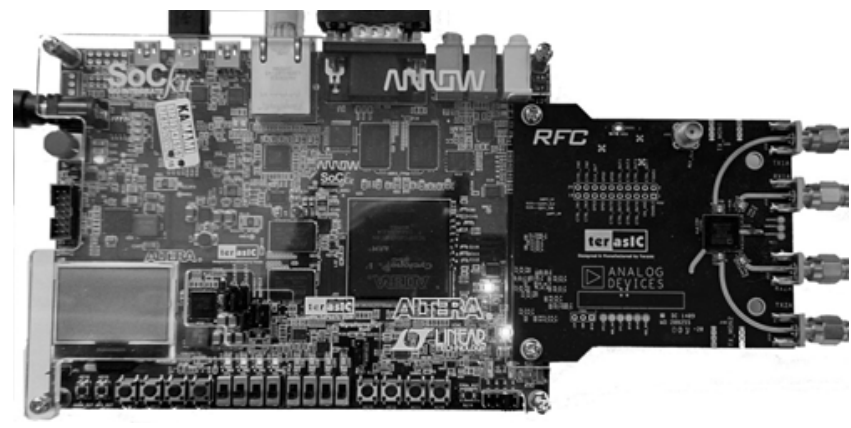

Fig. 5. Appearance of a prototype of the debug module of the modem equipment

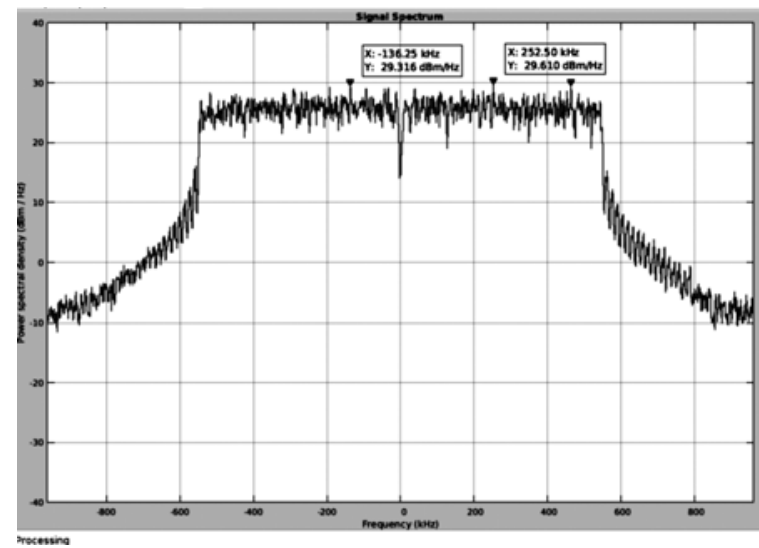

Fig. 6. A signal range with OFDM modulation in the main frequency band

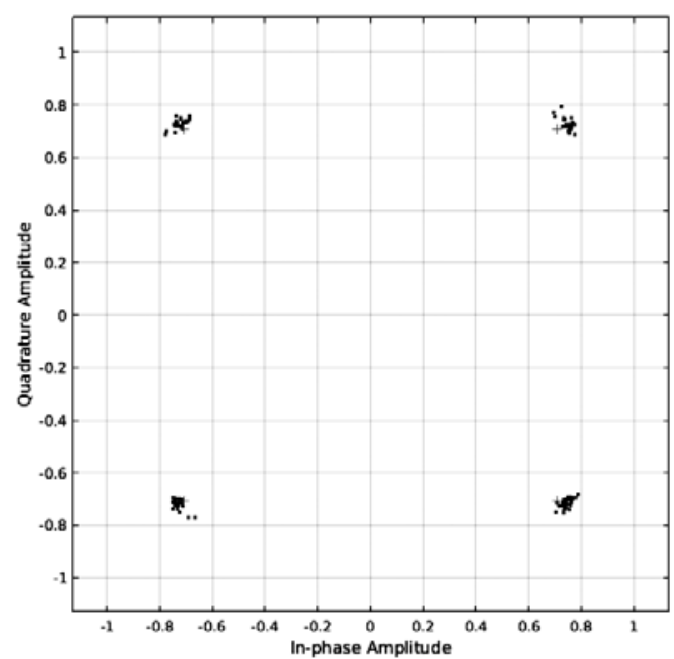

Fig. 7. Signal constellation on a demodulator input after phase and time lock for modulation QPSK

\section{Conclution}

The features of modem equipment construction of troposcatter stations with high data transfer rate are provided. The specific features of modem equipment construction of the troposphere stations are presented with high-rate of information transfer and assured quality. To achieve the boundary parameters of troposcatter station provides the use in modem equipment of new technical and architectural solutions, in particular, spectrally efficient modulation types (OFDM plus linear modulation) and error-correcting coding, efficient original algorithms of multi-level adaptation to changing operating conditions, the SDR technology, construction of structures frame of the physical layer and MAC layers. The variants of configuration of modem equipment are offered on the modes of operations of the small-sized troposcatter station.

\section{Acknowledgment}

This work is carried out within the framework of state research projects (No 2918, state registration number (SRN) - 0116U003771, No 2712-p, SRN 0114U002534, No 2815-p, SRN - 0116U004038 and contract DZ/40-2015 from 10.30.2015) on request of the Ministry of Education and Science of Ukraine.

\section{References}

1. F.H. Raab, R.Caverly, R. Campbell, M. Eron, J.B. Hecht, A. Mediano, D.P. Myer, and J.L. Walker, "HF, VHF, and UHF Systems and Technology", IEEE Trans. on Microwave Theory and Techniques, Vol. 50, No. 3, pp.888899, 2002.

2. R.L. Freeman, Radio System Design for Telecommunications, 3rd ed.: John Wiley \& Sons, Inc., 2007, 880 p.

3. M.Y. Ilchenko, S.O. Kravchuk, Modern telecommunication systems: Kiev, Naukova dumka, 2008, 328 p.

4. V.I. Slusar, M.O. Masesov, Ideology of Horizon Radiorelay Special Stations Building, Proceedings of VITI "KPI", Number 2, pp. 114-120, 2010.

5. T.N. Narytnik, V.I. Sliusar, "Construction Methods of Moden Tropospheric Radiorelay Station", International Scientific and Practical Conference "Problems of Infocommunications. Science and Technology" (PICS\&T 2014) October 14-17, 2014 Kharkov, Ukraine, pp. 178-181.

6. A.D. Wheelon, "Radio-Wave Scattering by Tropospheric Irregularities", Journal of Research of the National Bureau of Standards - D. Radio Propagation, Vol. 63D, No.2, September-October, pp. 205-239, 1959.

7. P. Monsen, "Adaptive processing can reduce the effects of fading on beyond-the-horizon digital radio link", IEEE Communications Magazine, No.1, pp. 16-25, 1980.

8. S.A. Isaakidis and T.D. Xenos, "Parabolic Equation Solution of Tropospheric Wave Propagation Using FEM", Progress In Electromagnetics Research, PIER 49, pp. 257271, 2004.

9. S.P. Shih, "A Study of Precipitation Effect on Tropospheric Electromagnetic Wave Propagation at Frequency 19.5 GHz", Terr. Atmos. Ocean. Sci., Vol. 19, No. 3, pp. 309-319, June 2008.

10. S. Sen and A. Nehorai, "OFDM MIMO Radar With Mutual-Information Waveform Design for Low-Grazing Angle Tracking”, IEEE Trans. on Signal Processing, Vol. 58, No. 6, pp. 3152-3162, JUNE 2010.

11. S.O. Kravchuk, "Portable tropospheric radiorelay stations", Dig. of the Tenth International Scientific conf. "Modern Challenges in Telecommunications", april 19-22, 2016, Kyiv, Ukraine. - pp. 305-307. 
12. S.O. Kravchuk, Principles for creating portable tropospheric radio relay stations // Dig. of the 9th International Scientific conf. "Modern Challenges in Telecommunications", april 21-25, 2016, Kyiv, Ukrane. - pp. 254-256.

13. F. Unkauf, "The Next Generation of Troposcatter Systems," Raytheon Technology Today, Issue 3, pp. 9-10, 2007.

14. A.G. Voitenko, N.N. Kaydenko, S.A. Kravchuk, T.N. Narytnik, "Designing the modem of modern tropospheric radiorelay stations", Digest. of 23rd International Crimean Conf. "Microwave equipment and telecommunication technologies", CriMico'2013. Sevastopol, September 8-13, 2013 - Sevastopol: Weber, 2013. - pp. 326-327.
15. N. Kaydenko, "Adaptive modulation and coding in a broadband wireless access systems", 23th International Crimean Conference on "Microwave and Telecommunication Technology", CriMico'2013. Sevastopol, on September 8-13, 2013. - P. 275-276.

16. N. Kaydenko, "Features choice of the modulation parameters and the error-correcting coding for optimal adaptive modulation systems with wireless broadband with OFDM", Dig. of the 8th International Scientific conf. "Modern Challenges in Telecommunications", 2014. - P. 141143.

Received in final form on May 31, 2016

\section{С.А. Кравчук, Н.Н. Кайденко.}

\section{Модемное оборудование тропосферных станций нового поколения}

Проблематика. Модемное оборудование тропосферных линий связи является важным компонентом современных средств телекоммуникаций. Рассматриваются теоретические и практические аспекты выбора предпочтительного варианта модемного оборудования с учетом совокупности показателей качества.

Цель. Представление особенностей построения модемного оборудования тропосферных станций нового поколения, которые смогут обеспечивать высокую скорость передачи информации с гарантированным качеством обслуживания в условиях сложных стационарных и нестационарных помех, присущих тропосферным каналам.

Методи. Поставленная цель достигается применением новых технических и архитектурных решений по построению модемного оборудования, спектрально-эффективных видов модуляции и кодирования, эффективных алгоритмов адаптации к изменяющимся условиям работы. Реализуемость предложенных подходов к построению модемного оборудования отрабатывается на прототипе такого оборудования на базе отладочных модулей HSMC ARRadio Daughter Card.

Результаты. Представлены особенности построения модемного оборудования тропосферных станций с высокой скоростью передачи информации. Для достижения предельных параметров таких станций предложено применение в модемном оборудовании новых технических и архитектурных решений, спектрально-эффективных видов модуляции (OFDM плюс линейная модуляция) и помехоустойчивого кодирования, эффективных алгоритмов адаптации к изменяющимся условиям работы, технологии SDR, структур кадров физического уровня. Предложены варианты конфигурации модемного оборудования применительно к режимам работы малогабаритной тропосферной станции.

Выводы. Предложены способы улучшения характеристик модемов для повышения эффективности современных малогабаритных тропосферных радиорелейных станций.

Ключевые слова: тропосферная связь, тропосферные станции, модемное оборудование, адаптация, программноопределяемое радио, канальные конфигурации.

\section{С.О. Кравчук, М.М. Кайденко.}

\section{Модемне обладнання тропосферних станцій нового покоління}

Проблематика. Модемне обладнання тропосферних ліній зв'язку є важливим компонентом сучасних засобів телекомунікацій. Розглядаються теоретичні та практичні аспекти вибору кращого варіанту модемного обладнання 3 урахуванням сукупності показників якості.

Мета. Представлення особливостей побудови модемного обладнання тропосферних станцій нового покоління, які зможуть забезпечувати високу швидкість передачі інформації з гарантованою якістю обслуговування в умовах складних стаціонарних і нестаціонарних завад, властивих тропосферним каналам.

Методи. Поставлена мета досягається застосуванням нових технічних і архітектурних рішень 3 побудови модемного обладнання, спектрально-ефективних видів модуляції і кодування, ефективних алгоритмів адаптації до постійно змінюваних умов роботи. Реалізація запропонованих підходів до побудови модемного обладнання відпрацьовується на прототипі такого обладнання на базі налагоджувальних модулів HSMC ARRadio Daughter Card.

Результати. Представлені особливості побудови модемного обладнання тропосферних станцій з високою швидкістю передачі інформації. Для досягнення граничних параметрів таких станцій запропоновано застосування в модемному обладнанні нових технічних і архітектурних рішень, спектрально-ефективних видів модуляції (OFDM плюс лінійна модуляція) і завадостійкого кодування, ефективних алгоритмів адаптації до постійно змінюваних умов роботи, технології SDR, структур кадрів фізичного рівня. Запропоновано варіанти конфігурації модемного обладнання стосовно режимам роботи малогабаритної тропосферного станції.

Висновки. Запропоновано способи поліпшення характеристик модемів для підвищення ефективності сучасних малогабаритних тропосферних радіорелейних станцій.

Ключові слова: тропосферний зв'язок, тропосферні станції, модемне обладнання, адаптація, радіо, що визначається програмно, канальні конфігурації. 